\title{
The surgical burden of breast disease in KwaZulu-Natal province
}

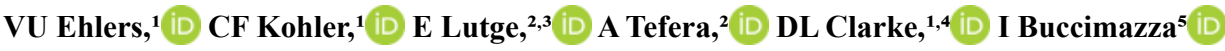 \\ ${ }^{1}$ Department of Surgery, Pietermaritzburg Metropolitan Hospital Complex, KwaZulu-Natal Department of Health, South Africa \\ ${ }^{2}$ Epidemiology Unit, KwaZulu-Natal Department of Health, South Africa \\ ${ }^{3}$ School of Nursing and Public Health, University of KwaZulu-Natal, South Africa \\ ${ }^{4}$ Department of Surgery, College of Health Sciences, Nelson R Mandela School of Medicine, University of KwaZulu-Natal, South Africa \\ ${ }^{5}$ Department of Surgery, Inkosi Albert Luthuli Hospital, KwaZulu-Natal Department of Health, South Africa
}

Corresponding author, email: ehlers.vincent@gmail.com

Background: The current surgical workload assessments in KwaZulu-Natal (KZN) are inadequate to inform strategies to improve surgical services. Breast diseases have a well-defined spectrum and surgical treatment options, analysis of which could guide health policy in the field. This project aimed to quantify and analyse the operative workload for breast pathology in KZN.

Method: A retrospective review of breast-related operations conducted at public sector hospitals in KwaZulu-Natal province between 1 July and 31 December 2015 was undertaken. Data was collected from theatre operative registers and manually categorised as follows: sepsis, benign pathology, malignant pathology, and by hospital, according to geographic location, and complexity of care to determine factors to improve the service for breast care in the province.

Results: In the 6-month study period, 13282 general surgical procedures were performed of which 776 (5.8\%) were breast-related operations. There were $372(47.9 \%)$ operations for breast sepsis, $140(18 \%)$ for benign breast lesions, 17 $(2.2 \%)$ for cosmetic indications and $27(3.5 \%)$ for diagnostic procedures. There were $223(28.7 \%)$ procedures for nonbenign disease: 21 (2.6\%) wide local excisions (WLE), 203 (26.2\%) mastectomies of which 161 (72.2\%) mastectomies had an axillary lymph node dissection and 26 (11.7\%) were performed as onco-plastic procedures. Hospitals in the Durban and Pietermaritzburg metropolitan areas performed $75 \%$ of the breast-related procedures. The majority (69.6\%) of sepsis-related procedures were performed at secondary/regional facilities, while $58.3 \%$ of non-benign breast surgeries were performed at tertiary and quaternary centres.

Conclusion: Breast sepsis accounts for almost $50 \%$ of the surgery and is mainly dealt with at hospitals above district level. One-third of breast surgery in KZN province is for non-benign disease. There is a paucity of breast-conserving surgery. Elucidation of these observations can guide improvement in the provincial breast care service.

Keywords: breast surgery, breast pathology, breast cancer, general surgery

\section{Introduction}

Low- and middle-income countries (LMICs), specifically in sub-Saharan Africa, have a deficit in health services and systems' research. The lack of evidence results in difficulties in creating surgical plans and research agendas, while further increasing the risk of services being inefficient or ineffective. ${ }^{1,2}$ South Africa faces a complex mix of surgical disease, which includes emergency surgery, trauma, benign surgical conditions and surgical oncology. There are also a number of long-term trends which impact the management of this burden. ${ }^{3,4}$ These include the increasing degree of surgical sub-specialisation within what was once considered "general surgery" as well as the need for multidisciplinary teams of surgeons, oncologists, radiologists and pathologists to appropriately coordinate the treatment of surgical oncology. ${ }^{5}$ These trends have directly impacted the management of breast pathology, which itself covers a spectrum of conditions ranging from benign to malignant. The assessment of breast disease is difficult as malignant conditions need to be identified and this may require access to sophisticated imaging and diagnostic services. In addition, malignant disease requires treatment algorithms involving access to advanced oncological therapeutic services. Some benign conditions may also require ongoing access to these advanced services. This makes planning for breast services complex, and for these reasons it is imperative that reliable data regarding the burden of breast pathology be captured to facilitate planning. In light of the above, this paper focuses on surgery for breast-related conditions and aims to quantify the operative workload for breast related pathology in the province of KwaZulu-Natal (KZN) over a six-month period, and to grade the type of procedures according to complexity, indication and geographical distribution. It is hoped that this data may provide evidence to support the ongoing development of breast care services in the province.

\section{Clinical setting}

KZN province is situated on the eastern seaboard of South Africa and has an area of $94361 \mathrm{~km}^{2}$ and a population of just over 10 million people. It has a densely inhabited coastal area around the port city of Durban as well as a number of other urban conurbations namely Pietermaritzburg, in the 
midlands, the Ladysmith/Newcastle area in the north west and a large port at Richards Bay, two hours north of Durban. However, about half of the population is rural and lives in districts with high poverty and inequality indices. There are 37 district hospitals, 12 regional hospitals, three tertiary hospitals and a single central quaternary centre in the province. Only two dedicated Breast Units exist in the province: one in Durban at Inkosi Albert Luthuli Central Hospital and the other at Grey's Hospital in Pietermaritzburg. The units offer a full spectrum of diagnostic and surgical breast services. In patients with breast cancer, weekly multidisciplinary team meetings determine the sequence and type of multimodal treatment. Advanced oncoplastic surgery techniques are available for all patients requiring breast-conserving surgery or mastectomy with immediate reconstruction. The Breast Units are largely ambulatory diagnostic services which assess the full spectrum of breast pathology. The exception is puerperal breast sepsis that is seen at emergency departments and treated by general surgeons across the province.

It is recommended that breast cancer surgery be centralised, while breast sepsis and some benign lumpectomies can be performed by surgical departments throughout the province.

\section{Methods}

This is a retrospective review of operations for breast pathology that were conducted at all regional, tertiary and a single quaternary hospital in the public sector of KZN province for the period 1 July-31 December 2015. Data was collected from operating theatre registers for this period. The variables collected included: the district in which the hospital is placed, the name of the operation, the date of the operation and the indication or outcome of operation if available. The data was entered into an Excel database and manually categorised by the primary authors. For the purpose of this review, all procedures involving the term 'breast' were included and subsequently categorised for analysis under the following categories: breast-related sepsis, benign mass removal, diagnostic procedures, treatment of nonbenign breast disease and level of facility.

\section{Statistics}

The data were quantitatively analysed and reported using non-parametric descriptive statistics. To gain an overview of the spectrum of disease and proportion of major subgroups within the sample, the frequency distribution of categories was reflected using percentages.

\begin{tabular}{|c|c|c|c|c|c|c|c|}
\hline $\begin{array}{l}\text { Name of } \\
\text { hospital }\end{array}$ & Level & $\begin{array}{l}\text { Total breast- } \\
\text { related } \\
\text { procedures } \\
(n=776)\end{array}$ & $\begin{array}{c}\text { Breast sepsis } \\
\text { procedures } \\
(n=372)\end{array}$ & $\begin{array}{l}\text { Non-benign } \\
\text { surgical } \\
\text { interventions } \\
(n=223)\end{array}$ & $\begin{array}{c}\text { Benign breast } \\
\text { procedures } \\
(n=140)\end{array}$ & $\begin{array}{l}\text { Cosmetic } \\
\text { procedures } \\
(n=15)\end{array}$ & $\begin{array}{c}\text { Diagnostic } \\
\text { procedures } \\
(n=16)\end{array}$ \\
\hline $\begin{array}{l}\text { Inkosi Albert } \\
\text { Luthuli }\end{array}$ & Quaternary & $78(10.1 \%)$ & $1(0.3 \%)$ & $49(22 \%)$ & $13(9.3 \%)$ & $10(66.7 \%)$ & $2(12.5 \%)$ \\
\hline King Edward & Tertiary & $145(18.7 \%)$ & $61(16.4 \%)$ & $31(13.9 \%)$ & $47(33.6 \%)$ & $2(13.3 \%)$ & $5(31.3 \%)$ \\
\hline Ngwelezane & Tertiary & $78(10.1 \%)$ & $48(12.9 \%)$ & $12(5.4 \%)$ & $13(9.3 \%)$ & & $1(6.2 \%)$ \\
\hline Grey's & Tertiary & $50(6.4 \%)$ & $3(0.8 \%)$ & $38(17 \%)$ & $6(4.3 \%)$ & $2(13.3 \%)$ & 0 \\
\hline Addington & $\begin{array}{l}\text { Regional/ } \\
\text { Secondary }\end{array}$ & $128(16.5 \%)$ & $82(22 \%)$ & $40(17.9 \%)$ & $4(2.9 \%)$ & 0 & 0 \\
\hline RK Khan & $\begin{array}{l}\text { Regional/ } \\
\text { Secondary }\end{array}$ & $83(10.7 \%)$ & $43(11.6 \%)$ & $15(6.7 \%)$ & $21(15 \%)$ & 0 & $3(18.8 \%)$ \\
\hline Stanger & $\begin{array}{l}\text { Regional/ } \\
\text { Secondary }\end{array}$ & $67(8.6 \%)$ & $59(15.9 \%)$ & $1(0.4 \%)$ & $5(3.6 \%)$ & $1(6.7 \%)$ & $1(6.2 \%)$ \\
\hline Edendale & $\begin{array}{l}\text { Regional/ } \\
\text { Secondary }\end{array}$ & $63(8.1 \%)$ & $28(7.5 \%)$ & $24(10.8 \%)$ & $11(7.9 \%)$ & 0 & 0 \\
\hline $\begin{array}{l}\text { Prince } \\
\text { Mshiyeni }\end{array}$ & $\begin{array}{l}\text { Regional/ } \\
\text { Secondary }\end{array}$ & $35(4.5 \%)$ & $18(4.8 \%)$ & $4(1.8 \%)$ & $10(7.1 \%)$ & 0 & $3(18.8 \%)$ \\
\hline Ladysmith & $\begin{array}{l}\text { Regional/ } \\
\text { Secondary }\end{array}$ & $34(4.4 \%)$ & $20(5.4 \%)$ & $9(4 \%)$ & $5(3.6 \%)$ & 0 & 0 \\
\hline $\begin{array}{l}\text { Port } \\
\text { Shepstone }\end{array}$ & $\begin{array}{l}\text { Regional/ } \\
\text { Secondary }\end{array}$ & $12(1.5 \%)$ & $6(1.6 \%)$ & 0 & $5(3.6 \%)$ & 0 & $1(6.2 \%)$ \\
\hline Queen Nandi & $\begin{array}{l}\text { Regional/ } \\
\text { Secondary }\end{array}$ & $2(0.3 \%)$ & $20.5 \%)$ & 0 & 0 & 0 & 0 \\
\hline Madadeni & $\begin{array}{l}\text { Regional/ } \\
\text { Secondary }\end{array}$ & $1(0.1 \%)$ & $1(0.3 \%)$ & 0 & 0 & 0 & 0 \\
\hline $\begin{array}{l}\text { Mohatma } \\
\text { Gandhi }\end{array}$ & $\begin{array}{l}\text { Regional/ } \\
\text { Secondary }\end{array}$ & 0 & 0 & 0 & 0 & 0 & 0 \\
\hline Newcastle & $\begin{array}{l}\text { Regional/ } \\
\text { Secondary }\end{array}$ & 0 & 0 & 0 & 0 & 0 & 0 \\
\hline St Aidens & $\begin{array}{l}\text { Regional/ } \\
\text { Secondary }\end{array}$ & 0 & 0 & 0 & 0 & 0 & 0 \\
\hline Total & & 776 & 372 & 233 & 140 & 15 & 16 \\
\hline
\end{tabular}




\section{Results}

During the six-month study period, 13282 general surgical procedures were performed in KZN province. Seven hundred and seventy-six $(5.8 \%)$ were for breast-related procedures. Table I summarises the indications for breast surgery in the province.

\section{Geographic and hospital distribution}

The majority of operations related to breast pathology were concentrated around the major cities of Durban, Pietermaritzburg and Richard's Bay. Five facilities in the greater Durban region contributed $60.5 \%$ of breast-related procedures, followed by $14.5 \%$ from the two facilities in Pietermaritzburg, and $10.4 \%$ from the two facilities near Richard's Bay. Three regional hospitals did not perform any breast operations during the study period. Quaternary and tertiary hospitals performed the majority $(58.3 \%)$ of nonbenign breast surgeries, while the secondary institutions performed the majority $(69.6 \%)$ of sepsis-related operations. Figure 1 is a map showing the distribution of all breast related surgeries across the province.

\section{Breast sepsis $(n=372)$}

Three hundred and seventy-two $(47.9 \%)$ operative procedures were performed for breast sepsis, of which 359

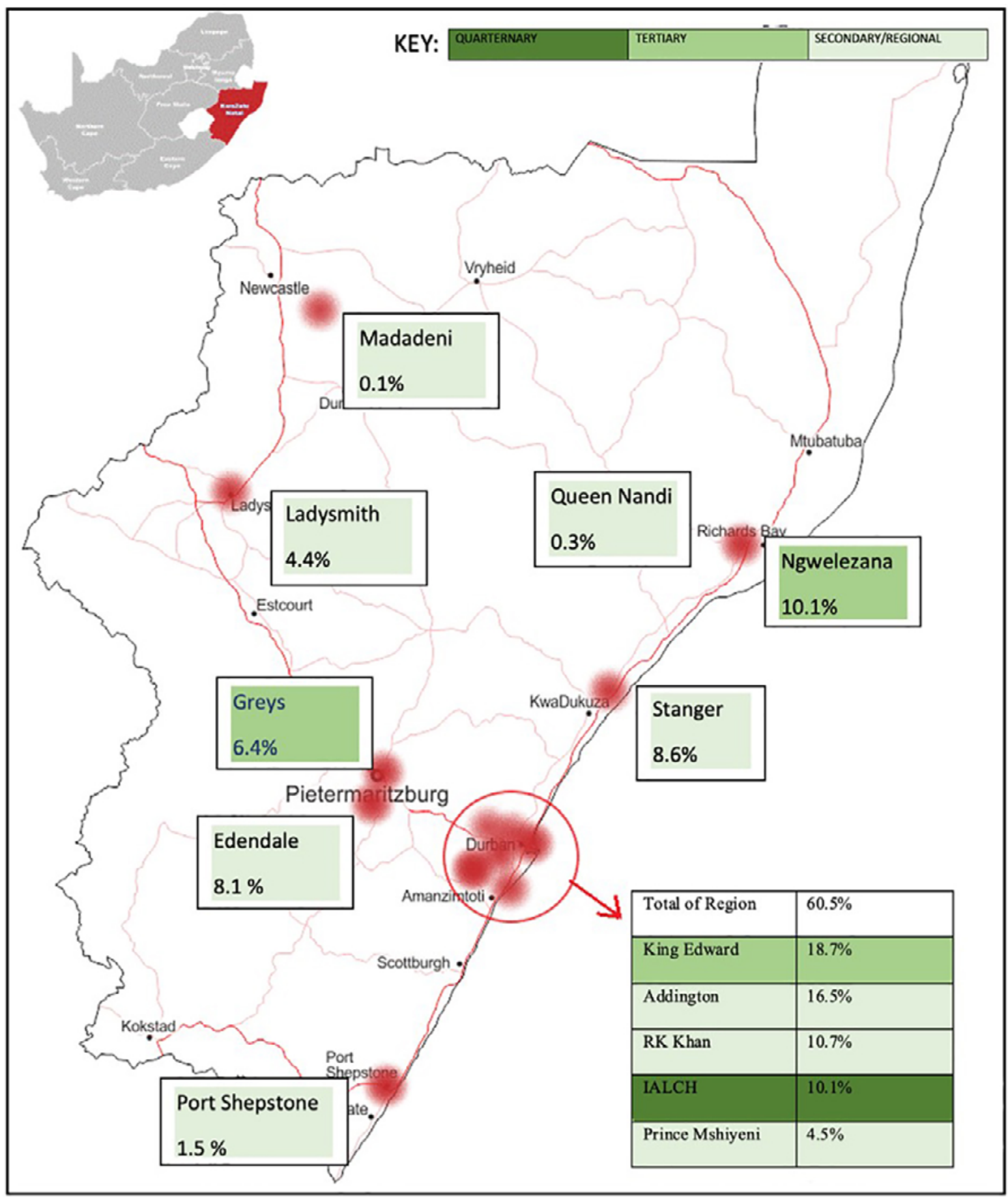

Figure 1: A map of KZN indicating the total breast procedures performed at each of the participating regional, tertiary and quaternary hospitals in the province

Image adapted from: https://d-maps.com/carte.php? num car $=89567 \&$ lang $=$ en 
$(46.3 \%)$ were incision and drainage of breast abscesses, nine $(1.2 \%)$ debridement of wounds on the breast and four $(0.5 \%)$ carbuncle excisions.

\section{Benign breast pathology $(n=140)$}

There were $140(18 \%)$ procedures for benign breast lesions. These were subdivided into: 49 (6.3\%) fibroadenomas, 73 (9.4\%) lumpectomies of unspecified mass, a single phyllodes tumour and 17 (2.2\%) other miscellaneous benign procedures, such as duct excisions, cyst and skin nodule excisions.

\section{Non-benign breast disease $(n=223)$}

Two hundred and twenty-three $(28.7 \%)$ operations were for non-benign disease. There were $20(2.6 \%)$ wide local excision (WLE). A single WLE included an axillary lymph node dissection (ALND). Mastectomies contributed the remaining $203(26.2 \%)$ procedures, of which 161 (72.2\%) included an ALND. In five (2.2\%) mastectomies, a sentinel lymph node biopsy (SLNB) was also performed. Twentyfour $(3.1 \%)$ oncoplastic surgery procedures associated with mastectomies or breast-conserving surgeries were performed. These included contralateral reductions and symmetry adjustments.

Of the 203 mastectomies, $180(88.7 \%)$ were unilateral, 18 $(8.9 \%)$ bilateral and in five cases this was unspecified. Table II shows the total number of mastectomies, including those with lymph node dissections and SLNB.

\section{Cosmetic procedures $(n=15)$}

There were $15(1.9 \%)$ purely cosmetic procedures, including breast reduction and removal of accessory breast tissue. The indications for the latter breast reductions were not recorded in the available data.

\section{Diagnostic procedures $(n=27)$}

There were 27 (3.5\%) procedures undertaken for diagnostic purposes. Of these, $16(2.1 \%)$ were performed in isolation and included excisional biopsies, incisional biopsies and two SLNB. The remaining 11 diagnostic procedures were performed in conjunction with non-benign therapeutic and septic procedures; this accounts for the overlap of procedure numbers within the dataset.

\section{Discussion}

There is a significant burden of breast-related pathology requiring surgical treatment in KZN. This burden comprises roughly six per cent of the total general surgical procedures within the province. Attempts to streamline the process of care for breast pathology and to develop referral algorithms are warranted. ${ }^{6}$

A third of all breast-related procedures were for malignant disease. There are 33 mastectomies for cancer each month, suggesting an annual load of just over 400 mastectomies for cancer in the province. Mastectomy is performed at most regional and all tertiary centres in the province. This is appropriate as the technical aspects of the operation can be standardised and the operation can be performed safely without recourse to advanced anaesthetic and ICU care. Of note is the high rate of mastectomy as opposed to that of WLE and the relatively low rate of SLNB. This suggests that most of the breast cancer being treated is advanced and as such is not suitable for breast-conserving surgery. The late presentation of disease is in keeping with other studies in sub-Saharan Africa. The delays in diagnosis reflect both poor health-seeking behaviour in the patient population and the inadequacies of the primary healthcare system for early diagnosis and appropriate referral. ${ }^{7-9}$ This may reflect the lack of essential skills to examine masses and perform diagnostic procedures at the district levels, which impedes appropriate and early referrals. What must be understood is that each patient undergoing a mastectomy requires multidisciplinary management involving chemotherapy and radiotherapy. This care cannot be delivered at each regional centre and this care needs to be centralised. In this regard, the management of breast cancer differs to that of other complex cancers in that the operation can be decentralised but the adjuvant and

\begin{tabular}{|c|c|c|c|c|c|c|}
\hline Name of hospital & Level of facility & $\begin{array}{c}\text { Total } \\
\text { non-benign } \\
\text { procedures } \\
(\boldsymbol{n}=\mathbf{2 2 3})\end{array}$ & $\begin{array}{l}\text { Mastectomies } \\
\text { with } \\
\text { axillary clearance } \\
(n=161)\end{array}$ & $\begin{array}{c}\text { Isolated } \\
\text { mastectomies } \\
\text { performed } \\
(n=37)\end{array}$ & $\begin{array}{l}\text { Mastectomies } \\
\text { with SLNB } \\
(n=5)\end{array}$ & $\begin{array}{l}\text { Wide local } \\
\text { excisions } \\
(n=20)\end{array}$ \\
\hline Inkosi Albert Luthuli & Quaternary & $49(22 \%)$ & $30(18.6 \%)$ & $14(37.8 \%)$ & $4(80 \%)$ & 1 \\
\hline Grey's & Tertiary & $38(17 \%)$ & $33(20.5 \%)$ & $4(10.9 \%)$ & $1(20 \%)$ & 0 \\
\hline King Edward & Tertiary & $31(13.9 \%)$ & $22(13.7 \%)$ & $3(8.1 \%)$ & 0 & 6 \\
\hline Ngwelezane & Tertiary & $12(5.4 \%)$ & $8(5 \%)$ & $3(8.1 \%)$ & 0 & 1 \\
\hline Addington & $\begin{array}{l}\text { Regional/ } \\
\text { Secondary }\end{array}$ & $40(17.9 \%)$ & $30(18.6 \%)$ & $7(18.9 \%)$ & 0 & 3 \\
\hline Edendale & $\begin{array}{l}\text { Regional/ } \\
\text { Secondary }\end{array}$ & $24(10.8 \%)$ & $21(13 \%)$ & $3(8.1 \%)$ & 0 & 0 \\
\hline RK Khan & $\begin{array}{l}\text { Regional/ } \\
\text { Secondary }\end{array}$ & $15(6.7 \%)$ & $7(4.3 \%)$ & 0 & 0 & 8 \\
\hline Ladysmith & $\begin{array}{l}\text { Regional/ } \\
\text { Secondary }\end{array}$ & $9(4 \%)$ & $8(5 \%)$ & $1(2.7 \%)$ & 0 & 0 \\
\hline Prince Mshiyeni & $\begin{array}{l}\text { Regional/ } \\
\text { Secondary }\end{array}$ & $4(1.8 \%)$ & $2(1.3 \%)$ & $2(5.4 \%)$ & 0 & 0 \\
\hline Stanger & $\begin{array}{l}\text { Regional/ } \\
\text { Secondary }\end{array}$ & $1(0.4 \%)$ & 0 & 0 & 0 & 1 \\
\hline
\end{tabular}


neoadjuvant care cannot. Complex gastrointestinal cancer surgery needs to be centralised in terms of both the operation and the adjuvant and neoadjuvant care. ${ }^{10} \mathrm{KZN}$ province has tertiary centres that are capable of performing the complex surgical procedures, however, the resources to provide the adjuvant and neoadjuvant care are not as widely available. Future planning around the delivery of care for breast disease needs to take this into consideration.

The substantial burden of breast sepsis requiring surgery may well reflect inadequate primary care services, as breast sepsis should ideally be detected early and managed with aspiration and antibiotics rather than surgery. ${ }^{11,12}$ Previous analysis from this same macro-data set has shown that most soft tissue sepsis is managed at regional and tertiary institutions rather than district hospitals. This suggests that district hospitals are not providing the expected level of surgical care and that this workload is being transferred to higher levels of care. ${ }^{13,14}$

\section{Study limitations}

The major limitation to this study is the lack of detail of the recorded data. The data were extracted from the operative logbooks and therefore lack supporting clinical data apart from the name of the operation. The diagnostic procedures are likely to be underrepresented in the data set due to a large proportion of diagnostic procedures being performed as a minor procedure outside of a theatre operating room. This same limitation may exist for septic procedures where simple abscess incision and drainage are frequently done outside of the operating theatre.

\section{Conclusion}

There is a significant load of breast pathology requiring surgical care in KZN province, of which just under one third is for non-benign disease and nearly half is secondary to breast sepsis. Improving data collection and standardising operative records amongst facilities will allow for the development of evidence-based strategies to meet the surgical workload of the province. Skills development programmes for the management of breast sepsis are warranted at district level facilities to avoid over-burdening regional and tertiary facilities. The ongoing development and strengthening of breast-related sub-specialist services is warranted to appropriately manage the entire spectrum of breast pathology.

\section{Conflict of interest}

The authors declare no conflict of interest.

\section{Funding source}

None.

\section{Ethical approval}

The study was approved by the Biomedical Research Committee of the University of KwaZulu-Natal (reference: BE528/16) and by the KZN Health Research and Knowledge Management Unit (reference: KZ_2016RP21_975).

\section{ORCID}

VU Ehlers (iD) https://orcid.org/0000-0002-3027-1712 CF Kohler (iD https://orcid.org/0000-0001-5159-9971
E Lutge (iD) https://orcid.org/0000-0003-0272-0100

A Tefera (iD https://orcid.org/0000-0003-1036-2796

DL Clarke (iD https://orcid.org/0000-0002-8467-1455

I Buccimazza (D) https://orcid.org/0000-0002-5399-3101

\section{REFERENCES}

1. Katz MG, Price RR, Nunez JM. Local research catalyses National Surgical Planning comment on "Global Surgery - informing national strategies for scaling up surgery in sub-Saharan Africa". Int $J$ Health Policy Manag. 2018;7(11):1058-60. https://doi.org/10.15171/ijhpm.2018.78.

2. Gajewski J, Bijlmakers L, Brugha R. Global surgery informing national strategies for scaling up surgery in subSaharan Africa. Int J Health Policy Manag. 2018;7(6):481-4. https://doi.org/10.15171/ ijhpm.2018.27.

3. Dell AJ, Kahn D. Surgical resources in South Africa: an international comparison and deficit calculation. World J Surg. 2018;42:541-8.

4. Meara JG, Leather AJ, Hagander L, et al. Global Surgery 2030: evidence and solutions for achieving health, welfare, and economic development. Lancet. 2015;386:569-624.

5. Licitra L, Keilholz U, Tahara M, et al. Evaluation of the benefit and use of multidisciplinary teams in the treatment of head and neck cancer. Oral Oncol. 2016;59:73-9. https://doi. org/10.1016/j.oraloncology.2016.06.002.

6. Pace LE, Shulman LN. Breast cancer in sub-Saharan Africa: challenges and opportunities to reduce mortality. Oncologist. 2016;21(6):739-44. https://doi.org/10.1634/theon cologist.2015-0429.

7. Ohene-Yeboah M, Adjei E. Breast cancer in Kumasi, Ghana. Ghana Med J. 2012;46(1):8-13.

8. Rayne S, Lince-Deroche $\mathrm{N}$, Hendrickson $\mathrm{C}$, et al. Characterising breast conditions at an open-access breast clinic in South Africa - a model that is more than cancer care for a resource-limited setting. BMC Health Serv Res. 2017;17(1):63. https://doi.org/10.1186/s12913-016-1959-4.

9. Rayne S, Schnippel K, Kruger D, Benn CA, Firnhaber C. Delay to diagnosis and breast cancer stage in an urban South African breast clinic. S Afr Med J. 2019;109(3):159-63. https://doi.org/10.7196/SAMJ.2019.v109i3.13283.

10. Loots E, Ramdial PK, Sartorius B, Mulder CM, Clarke DL. Malignant and pre-malignant oesophageal pathology in a South African teaching hospital. S Afr J Surg. 2018;56(1):214. https://doi.org/10.17159/2078-5151/2018/v56n1a2076.

11. Dixon JM, Khan LR. Treatment of breast infection. BMJ. 2011;342:d396. https://doi.org/10.1136/bmj.d396.

12. Scott-Conner CE, Schorr SJ. The diagnosis and management of breast problems during pregnancy and lactation. Am J Surg. 1995;170:401-5. https://doi.org/10.1016/S00029610(99)80313-4.

13. Ehlers V, Kohler C, Di Rago N, et al. Soft tissue sepsis places a massive burden on regional and tertiary surgical services in KZN Province South Africa. World J Surg. 2020;44:2526-32. https://doi.org/10.1007/s00268-020-05510-5.

14. Tefera A, Lutge E, Clarke DL. Bellwether operations in KwaZulu-Natal Province, South Africa, are performed at regional and tertiary rather than district hospitals. S Afr Med J. 2020;110(5):374-6. https://doi.org/10.7196/SAMJ.2020. v110i5.14218. 